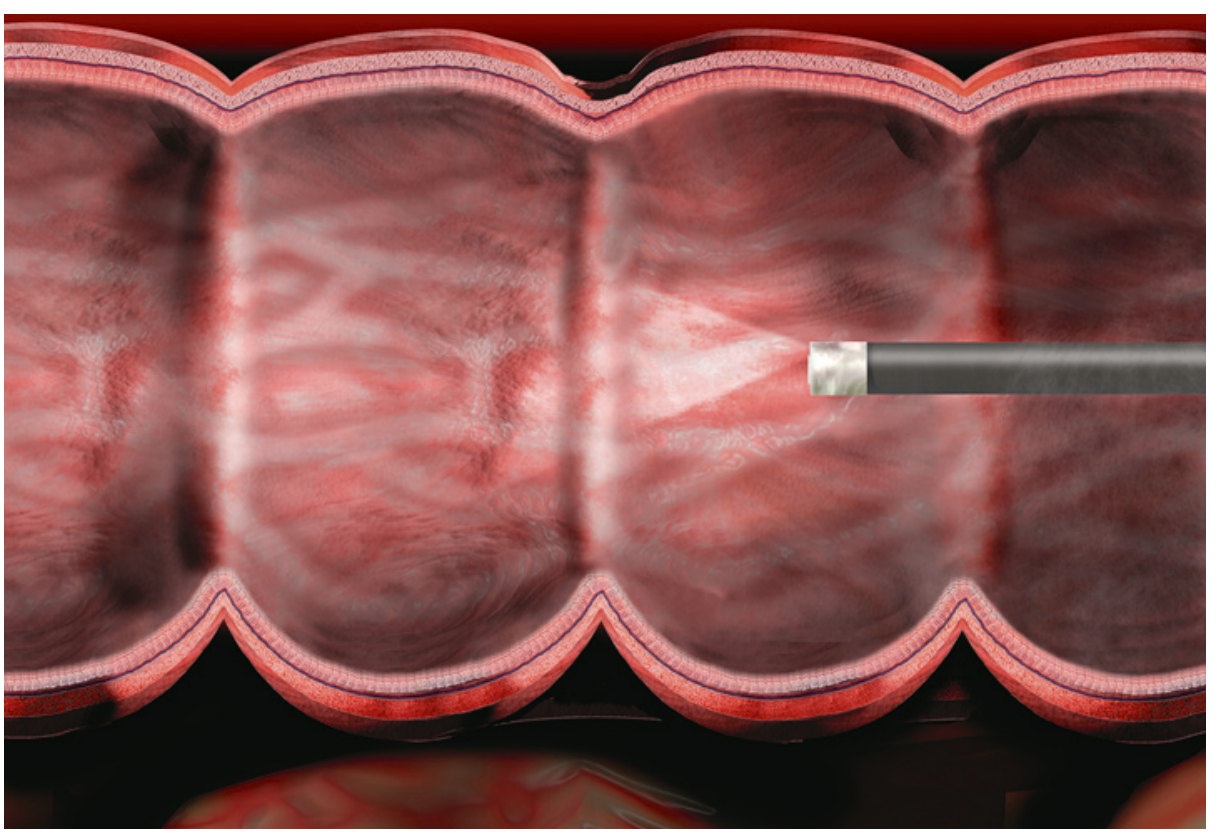

Illustrasjon: Science Photo Library

\title{
Tarmkreftscreening hos eldre?
}

Koloskopiscreening gir lavere forekomst av kolorektal kreft hos mennesker opp til 75 års alder. Det viser en ny studie.

Nasjonalt råd for prioritering i helsetjenesten har nylig anbefalt innføring av screening for kolorektal kreft i Norge (1). Koloskopi er en av metodene som vurderes. I de fleste europeiske land der man har innført screening, stopper man ved 75 år, mens man i USA ikke har noen øvre aldersgrense. Nylig ble den hittil største studien av koloskopiscreening i aldersgruppen 70-79 år publisert i Annals of Internal Medicine (2).

Studien er et amerikansk-norsk samarbeidsprosjekt med data fra 1,3 millioner amerikanere forsikret i Medicare. Det ble brukt avanserte statistiske metoder, såkalt kausal inferens, der man simulerte 520 randomiserte studier i datasettet. Insidens av kolorektal kreft ble sammenlignet hos friske individer som var blitt screenet med koloskopi og personer som ikke var blitt screenet. Oppfølgingstiden var på opptil åtte år. For aldersgruppen 70-74 år var insidensen av kolorektal kreft 2,62\% hos ikke-screenede og $2,19 \%$ hos screenede (forskjell 0,42\%; $95 \%$ $\mathrm{KI}-0,24--0,63)$. For aldersgruppen 75-79 år var tallene $2,97 \%$ for ikke-screenede og $2,84 \%$ for dem som ble screenet (forskjell $0,14 \% ; 95 \% \mathrm{KI}-0,41-0,16$ ).

30-dagerskomplikasjonsraten etter koloskopi var dobbelt så høy hos 75-79-åringer (10,3 hendelser per 1000 screenede) som hos personer i alderen 71 - 74 år $(5,6$ hendelser per 1000 screenede).

- Denne store studien viser at koloskopiscreening har liten effekt hos dem som er over
Ordforklaringer

Koloskopiscreening: Screening for kolorektal kreft med bøyelig tarmkikkert etter oral tømming av tarmen med tømmingsvæske. Koloskopiscreening gjøres i USA og noen land i Europa.

Kausal inferens: Fagfelt innenfor statistikk og epidemiologi der man utvikler nye metoder for å forstå årsakssammenhenger.
74 år og innebærer betydelig større bivirkninger og komplikasjoner. Dette bekrefter vår nåværende anbefaling i Norge om tilby kolorektalscreening for mennesker opp til 74 års alder, sier den norske medforfatteren Michael Bretthauer.

\section{Forskningsgruppe \\ for klinisk effektforskning}

Studien er del av et større samarbeid mellom forskningsgruppen for klinisk effektforskning ved Universitetet i Oslo og Oslo universitetssykehus og forskningsgruppen for kausal inferens ved Harvard TH Chan School of Public Health i Boston. Samarbeidet har ført til flere store epidemiologiske studier innen kolorektal kreft og metodeutvikling innenfor kausal inferens. Kausal inferens er et nytt felt innen medisinsk statistikk og får for tiden stor oppmerksomhet i mange land.

\section{Kari Tveito}

Tidsskriftet

\section{Litteratur}

1. Innføring av et nasjonalt screeningprogram for tykk- og endetarmskreft. www.prioritering.no/ saker/innf\%C3\%B8ring-av-et-nasjonaltscreeningprogram-for-tykk-og-endetarmkreft (8.11.2016).

2. García-Albéniz X, Hsu J, Bretthauer M et al. Effectiveness of screening colonoscopy to prevent colo rectal cancer among Medicare beneficiaries aged 70-79 years: a prospective observational study. Ann Intern Med 2016. E-publisert 26.9.2016.

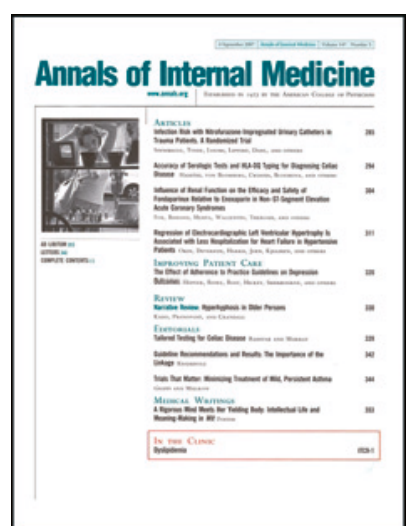

Artikkelen ble e-publisert 26.9.2016 i Annals of Internal Medicine, ett av verdens mest velrenommerte medisinske tidsskrifter 